\title{
Prologue to the special issue "Resources, energy and eco-innovation" in Mineral Economics
}

\author{
R. Bleischwitz $\cdot$ P. J. J. Welfens $\cdot$ Z. Zhang
}

Published online: 15 May 2012

(C) Springer-Verlag 2012

The global competition for natural resources-be it for minerals or energy or others - is widely discussed. Many scholars point to the issue of access as being a main constraint to open up new mining activities and get the resources to the market. This special issue of Mineral Economics looks at the global competition from the new angle of ecoinnovation activities - innovation across the material value chains of products and processes that lowers the material

R. Bleischwitz $(\square)$

Wuppertal Institute,

Wuppertal, Germany

e-mail: RBleischwitz@transatlanticacademy.org

R. Bleischwitz

College of Europe,

Bruges, Belgium

R. Bleischwitz

Transatlantic Academy,

Washington, DC, USA

\section{P. J. J. Welfens}

Jean Monnet Chair in European Economic Integration,

European Institute for International Economic Relations (EIIW),

University of Wuppertal,

Rainer-Gruenter-Str. 21,

42119 Wuppertal, Germany

e-mail: welfens@eiiw.uni-wuppertal.de

\section{P. J. J. Welfens}

AICGS/Johns Hopkins University,

Washington, DC, USA

\section{P. J. J. Welfens}

IZA,

Bonn, Germany

P. J. J. Welfens

Sciences Po,

Paris, France intensity of use while increasing service intensity and wellbeing (Eco-Innovation Observatory 2011). This perspective goes well beyond mining and includes the downstream activities of manufacturing industries, consumption activities as well as recycling on an international scale.

The international scale is important because the geography of commodity trade has changed. Russia has become the main commodity exporter; China is the biggest importer

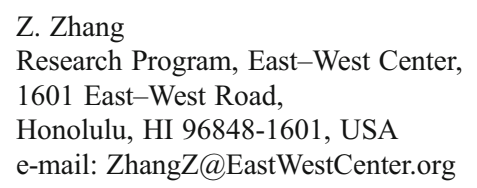

\section{Z. Zhang}

Center for Energy Economics and Strategy Studies and Research Institute for the Changing Global Environment, Fudan University, Shanghai, China

\section{Z. Zhang}

Institute of Policy and Management, Chinese Academy of

Sciences,

Beijing, China

\section{Z. Zhang}

China Centre for Urban and Regional Development Research, Peking University,

Beijing, China

\section{Z. Zhang}

Centre for Climate Economics and Policy, Crawford School of Economics and Government, The Australian National University, Canberra, Australia 
for minerals worldwide. Other emerging countries such as Brazil, South Africa and Indonesia are major players on commodity markets; countries in Africa and Central Asia are on the verge of catching up to Latin America as main hubs of supplying resources to the world market. Their endowments with natural resources offer opportunities to turn these assets into viable growth paths with development opportunities for the people (Collier 2011). The extent to which they pursue strategies towards open trade or resource nationalisms will be decisive for the new world order on resources and energy in the twenty-first century.

At the same time, the environmental challenges continue to rise. The recent report by the International Resource Panel of the United Nations Environment Program (Hertwich et al. 2010) indicates that mass materials such as iron ore, aluminium and steel are as environmentally intensive as fossil fuels if their full life cycle is taken into account. Producing and using them in the most sustainable manner thus is a key requirement towards any sustainable growth. It will require the development and application of new technologies including information and communication technology (ICT) as well as new institutional mind-sets to disseminate them from early demonstration into mass markets. Given the new geography of commodity trade, the role of emerging economies in that regard is of utmost importance.

This special issue underlines a number of important features in that regard: while the important role of green technology is undisputable and has started to evoke aspirations for "a resource revolution" (Richard et al. 2011), much less is known about:

1. The ways of how economies have started to adopt ecoinnovation along material chains and energy

2. How international markets shape and respond to these developments

3. The role of policies in facilitating eco-innovation markets

4. Macro-economic consequences of eco-innovation strategies

These features help to structure the articles of this special issue. All papers were originally prepared for the Third International Wuppertal Colloquium on "sustainable growth and resource productivity-harnessing industry and policy towards eco-innovation" that was jointly organised by the Wuppertal Institute (Raimund Bleischwitz), the European Institute for International Economic Relations at the University of Wuppertal (Paul Welfens) and the East-West Center in Honolulu (ZhongXiang Zhang) on 4-6 September 2010, in Brussels in the premises of the European Commission (DG ENV). The findings of the two previous colloquia also have been published (Bleischwitz et al. 2009, 2011).

Paul Ekins discusses the issue of whether environmentally sustainable growth is a feasible aspiration and, if so, how it might be brought about and how the levels of such growth would relate to those currently being experienced. The key issue is the nature, strength and consistency of the policy signal. While environmental tax reform emerges from the analysis as probably the most promising policy approach, the paper ends with a rather sombre conclusion that, despite this policy instrument's benefits, there are a number of political reasons why it is likely to be difficult to introduce.

By benchmarking green innovation, Rainer Walz and Wolfgang Eichhammer analyse competences for green technologies in newly industrializing countries (NICs). From a conceptual point of view, technological benchmarking of green technologies (sustainability benchmarking) can be distinguished from capability benchmarking. For both types of benchmarking, a top-down perspective (overall level of the economy) and a sectoral bottom-up perspective (focusing on the important field of industrial energy efficiency technologies) are taken. From a top-down view, it can be seen that some NICs have been catching up and are in the same benchmark clusters as a variety of current OECD countries. In the more detailed bottom-up view, this trend is also starting for industrial energy efficiency technologies; however, it is not as pronounced yet, as on the more aggregated level of all green technologies.

ZhongXiang Zhang discusses the finding that a hefty chunk of China's $\mathrm{CO}_{2}$ emissions is embedded in international trade, especially in exports. This raises the issue of who should be responsible for this portion of emissions and bearing the carbon cost of exports. China certainly wants importers to cover some, if not all, of that costs. While China's stance is understandable, this paper has argued from a broad and balanced perspective that if this is pushed too far, it will not help to find solutions to this issue. On the contrary, it can be to China's disadvantage for a number of reasons. However, aligning this responsibility with China does not necessarily suggest the sole reliance on domestic actions. In that context, the paper recommends specific actions that need to be taken internationally as well as domestically in order to effectively control the embedded $\mathrm{CO}_{2}$ emissions in China's trade.

Deniz Erdem looks at foreign direct investments (FDIs) and explains the relationship between FDIs and technologydetermined energy efficiency by considering the structural effects. By applying decomposition methodology and panel data analysis with country-specific effects, the paper points out that there is a significant correlation between FDI and technology-determined energy efficiency improvements in the eastern EU members and cohesion countries. These results affirm the existing theoretical basis regarding the positive effects of FDIs on technology level of host countries. One can conclude that economic integration indirectly contributes to efficient use of resources.

Raimund Bleischwitz outlines guidelines and pillars of a resource policy. Two reasons favour the formulation of such policy: a demand to increase sluggish resource productivity growth as well as environmental damages occurring along 
material flows at an international scale. The paper surveys recent empirical trends. The proposed guidelines for a resource policy-namely, market order, provision function, learning processes, market development and orientationare applied to develop four instruments as potential pillars of a future policy mix: a tax on construction minerals, an ecologically differentiated VAT tax, an international covenant for metals and an international convention for sustainable resource management. The paper finally concludes that despite all uncertainties and complexities, a well-designed resource policy is on the verge of becoming essential for unleashing eco-innovation dynamics.

Bernd Meyer, Mark Meyer and Martin Distelkamp investigate in the nature and significance of trade-off interrelationships with regards to material efficiency improvements within the German economy. The paper presents the outcomes of individual policy simulations by means of the PANTA RHEI model. Taxes, information and regulation activities are considered as policy instruments. The overall findings seem to confirm the green growth paradigm as the observed magnitude of economy-wide rebound effects appears unable to inhibit future absolute decoupling trends.

Paul Welfens and Christian Lutz examine the role of ICT with respect to both economic growth and green global modernization. The findings for the impact of an expansion of Green ICT in Germany show small significant effect on output but relatively more important effects on the reduction of greenhouse gases. Hence, the simulation results from the PANTA RHEI model suggest that Green ICT dynamics could be a useful element of sustainable development in Germany and the EU, respectively.
Coming back to the sweeping resource nationalism across the globe, it is however far from being clear to what extent these strategies shape eco-innovation and the prospects for sustainable growth. While high resource prices certainly drive those efforts, volatility and irrational supply strategies along with resource-related conflicts will increase uncertainties and risks. Thus, analysing international commodity markets will be an interesting research area with many different facets.

\section{References}

Bleischwitz R, Welfens P, Zhang ZX (eds) (2009) Sustainable growth and resource productivity - economic and global policy issues. Greenleaf, Sheffield

Bleischwitz R, Welfens P, Zhang ZX (eds) (2011) International economics of resource efficiency. Eco-innovation policies for a green economy. Springer, Berlin

Collier P (2011) The plundered planet: why we must-and how we can-manage nature for global prosperity. Oxford University Press, New York

EIO (EU Eco-Innovation Observatory) (2011) The eco-innovation challenge; pathways to a resource efficient Europe. Funded by the European Commission, DG Environment, Brussels. www.eco-innovation.eu

Richard D et al (2011) Resource revolution-meeting the world's energy, materials, food, and water needs. McKinsey Global Institute, London

Hertwich E, van der Voet E, Suh S, Tukker A et al (2010) Assessing the environmental impacts of consumption and production: priority products and materials. A report of the working group on the environmental impacts of products and materials to the International Panel for Sustainable Resource Management. UNEP, Nairobi 